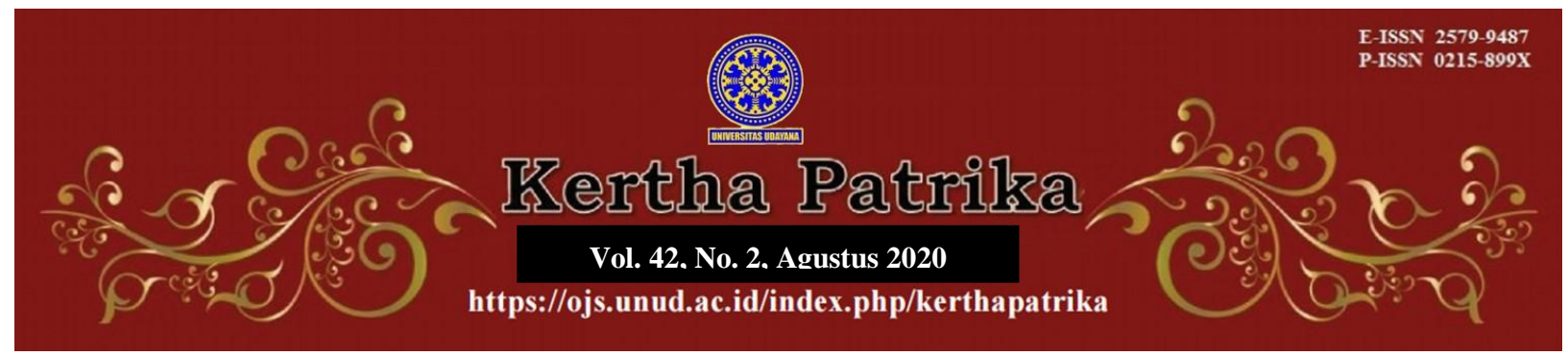

\title{
Paradigma Keadilan Restoratif Dalam Putusan Hakim
}

\section{Diah Ratna Sari Hariyanto ${ }^{1}$, Dewa Gede Pradnya Yustiawan ${ }^{2}$}

1Fakultas Hukum Universitas Udayana,

E-mail: diah_ratna@unud.ac.id

${ }^{2}$ Fakultas Hukum Universitas Udayana,

E-mail:pradnya_yustiawan@unud.ac.id

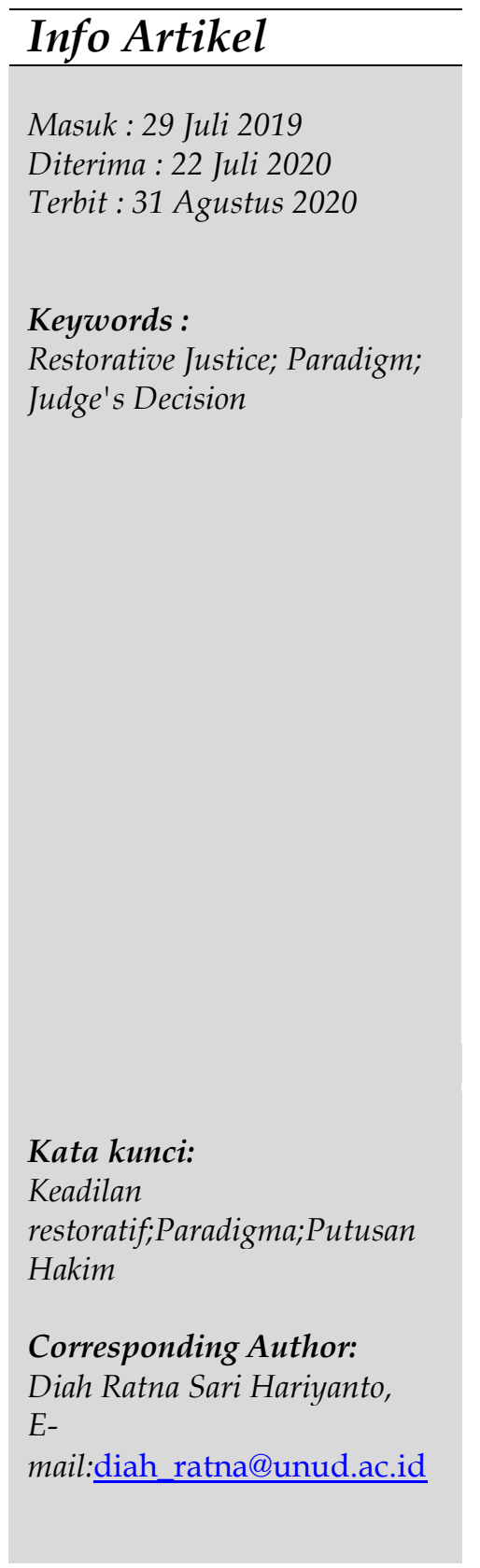

\begin{abstract}
The judge's unfair behavior has dominated reports to the Judicial Commission. Injustice, in fact, is one of the lowest value attitudes of judges according to Judicial Commission assessment results. The emergence of the concept of restorative justice that provides justice for all parties then seems to be a new hope that needs to be criticized academically. This paper aims to figure out judge's restorative justice paradigm in deciding criminal cases and the construction of a judge's decision with such a paradigm. This study is a normative legal research that uses case, statutory, and conceptual approaches. The results of the study suggested that the restorative justice paradigm that prioritizes restoration or improvement will seek to provide justice, legal certainty, and benefits, as well as realizing progressive and responsive law, so it is appropriate to be used as a judge paradigm in deciding a case. In constructingrestorative justice-based judges' decisions, judges do not only make decisions based on the Criminal Procedure Code, but also consider justice for all parties (victims, perpetrators of crime, and society). In addition, judges also do not make decisions based on retributive/retaliatory purposes of punishment but are adhering to the values, concepts, principles, and basics of restorative justice that prioritize restoration or improvement of the parties, fulfill the needs of the parties as well as strive for benefits.
\end{abstract}

\begin{tabular}{l} 
Abstrak \\
\hline Perilaku hakim yang tidak adil telah mendominasi laporan ke \\
Komisi Yudisial. Ketidakadilan nyatanya menjadi salah satu \\
nilaiterendah yang dimiliki hakim dari hasil pengukuran Komisi \\
Yudisial. Munculnya konsep keadilan restoratif yang \\
memberikan keadilan bagi semua pihak kemudian seolah menjadi \\
harapan baru yang perlu dikritisi secara akademik. Tulisan ini \\
bertujuan untuk menemukan paradigma keadilan restoratif \\
hakim dalam memutus perkara pidana dan konstruksi putusan \\
hakim yang berparadigma Keadilan Restoratif. Penelitian ini \\
menggunakan jenis penelitian hukum normatif dengan \\
pendekatan kasus, pendekatan perundang-undangan, dan \\
pendekatan konseptual.Hasil studimenunjukkan bahwa
\end{tabular}


DOI :
10.24843/KP.2020.v42.i02.p06 paradigma keadilan restoratif yang mengutamakan pemulihan atau perbaikan akan berupaya memberikan keadilan, kepastian hukum, dan kemanfaatan, serta mewujudkan hukum yang progresif dan responsif, sehingga tepat digunakan sebagai paradigma hakim dalam memutus suatu perkara. Dalam konstruksiputusan hakim berbasis keadilan restoratif, hakim tidak hanya membuat putusan berdasarkan KUHAP, namun mempertimbangkan pula keadilan bagi semua pihak (korban, pelaku kejahatan, dan masyarakat). Selain itu, hakim juga tidak memutus berdasarkan tujuan pemidanaan yang retributif/pembalasan namun berpegangan pada nilainilai, konsep, prinsip, serta dasar-dasar dari keadilan restoratif yang mengutamakan pemulihan atau perbaikan para pihak, pemenuhan kebutuhan para pihak serta mengupayakan kemanfaatan.

\section{Pendahuluan}

Keadilan akan menjadi abstrak dan dimaknai beragam tergantung pada paradigma seseorang dalam memandang keadilan itu sendiri. Adil bagi seseorang belum tentu adil bagi orang lain. Keadilan menjadi konsep yang rumit karena bersinggungan dengan "nilai" dan "rasa", meskipun demikian keadilan menjadi salah satu tujuan hukum yang harus dipenuhi terutama dalam hal "mengadili". Dalam konteks ini hakim memiliki peran dan kedudukan yang sangat penting untuk memberikan keadilan dalam setiap perkara yang diadilinya, karena putusan yang akan dijatuhkannya akan menentukan nasib banyak pihak.

Keadilan dalam sebuah putusan hakim adalah salah satu komponen yang sangat penting. M. Natsir Asnawi menyatakan bahwa hakim dalam membuat putusan sejatinya harus cermat dan hati-hati. Dalam konteks ini, hakim dituntut menggunakan seluruh potensinya untuk mengkonstatir, mengkualifisir, dan mengkonstituir. Pertimbangan hukum yang cukup dan relevan juga dibutuhkan dalam membuat suatu putusan hakim sebagai dasar kesimpulan dan ketetapan hakim dalam memutus perkara. ${ }^{1}$ Hal ini menunjukkan bahwa tugas hakim tidaklah mudah dalam membuat suatu putusan yang dapat memberikan keadilan bagi semua pihak. Mengutip dalam sebuah artikel menyatakan bahwa perilaku hakim yang tidak adil mendominasi laporan ke Komisi Yudisial. Hakim harus berintegritas dan adil. Ketidakadilan, keteguhan, dan keberpihakan menjadi hal terendah yang dimiliki hakim dari hasil pengukuran Komisi Yudisial. ${ }^{2} \mathrm{Hal}$ ini tentu perlu dikritisi.

Hakim berperan sentral dalam menjatuhkan putusan. Putusan hakim akan berisi berbagai pertimbangan atas fakta dan alat bukti yang ada dan pada akhirnya diputus

\footnotetext{
${ }^{1}$ Asnawi, M. N. (2014).Hermeneutika Putusan Hakim. Yogyakarta: UII Press. h. 4-5.

${ }^{2}$ Komisi Yudisial Republik Indonesia. KY Tekankan Hakim Harus Berintegritas dan Adil. Available fromhttps://www.komisiyudisial.go.id/frontend/news_detail/1084/ky-tekankan-hakim-harusberintegritas-dan-adil. (Diakses 2 Juni 2020).
} 
berdasarkan keyakinannya. ${ }^{3}$ Sebagai penegak hukum, hakim bermakna filosofi yang mulia karena tidak hanya memutus perkara. Hakim dituntut untuk selalu bijaksana dalam memandang nilai-nilai yang sangat berperan dalam penegakan hukum, demi menegakkan keadilan. ${ }^{4}$

Terkait dengan pemenuhan keadilan dalam putusan pengadilan, Hesti Septianita menyebutkan bahwa tentunya hakimharus merujuk undang-undang, namun hakimbukanlah corong undang-undang. Hakim adalahcorong kepatutan, keadilan, kepentingan umum,dan ketertiban umum. Dalam hal inilah,terletak rumusan keharusan hakim untuk memperhatikan nilai-nilaiyang hidup dalam masyarakat, ${ }^{5}$ sesuai dengan amanat yang telah diatur dalam Pasal 5 ayat (1) Undang-Undang Kekuasaan Kehakiman.Andri Winjaya Laksana juga mengemukakan bahwa terkait dengan pemenuhan keadilan, mengukur keadilan tidak hanya atasdasar pembalasan yang setimpal dari korban kepada pelaku. Kejahatan disembuhkan melalui dukungan kepada korban dan adanya tanggungjawab dari pelaku kejahatan, dengan bantuan dan pelibatan keluarga dan masyarakat (apabila diperlukan). ${ }^{6} \mathrm{Hal}$ ini menunjukkan bahwa keadilan harus dicari, digali, dan ditemukan oleh hakim, dengan berbagai pertimbangannya yang kerap dipengaruhi oleh paradigma yang dianut oleh hakim secara subyektif.

Kini dalam perkembangannya dikenal adanya keadilan restoratif (restorative justice) yang menurut penulis dapat menjadi solusi yang menawarkan keadilan yang dibutuhkan bagi masyarakat dan bagi penegakan hukum di Indonesia. Terkait dengan paradigma pemidanaan Sukardi menyebutkan bahwa saat ini dalam perkembangan hukum pidana terjadi pergeseran paradigma pemidanaan dari konsep restitutif justice (criminal justice) ke konsep restorative Justice. ${ }^{7}$

Menurut Yoachim Agus, restorative justice adalahkeadilan yang berpusat pada kebutuhan korban, pelaku kejahatan, dan masyarakat. ${ }^{8}$ Keadilan restoratif menjadi konsep yang menarik karena dapat mencakup kebutuhan keadilan semua pihak, tidak hanya bagi pihak pelaku, namun juga bagi pihak korban dan masyarakat. Memahami keadilan restoratif tentunya akan menemukan semangat yang mengarah untuk menyelesaikan masalah para pihak dalam hubungan sosial daripada mengutamakan

${ }^{3}$ Nurhafifah, N., \& Rahmiati, R. (2015). Pertimbangan Hakim dalam Penjatuhan Pidana Terkait Hal yang Memberatkan dan Meringankan Putusan. Kanun Jurnal Ilmu Hukum, 17(2), 344.

${ }^{4}$ Haryadi, L., \& Suteki, S. (2017). Implementasi Nilai Keadilan Sosial Oleh Hakim Dalam Perkara Lanjar Sriyanto dari Perspektif Pancasila dan Kode Etik Profesi Hakim. Law Reform, 13(2), 165. doi: 10.14710/lr.v13i2.16153, h. 165.

5Septianita, H. (2018). Keadilan Restoratif Dalam Putusan Pidana Anak. Jurnal Yudisial, 11(2), 205. doi: 10.29123/jy.v11i2.290, h. 205.

${ }^{6}$ Laksana, A. W. (2017). Keadilan Restoratif Dalam Penyelesaian Perkara Anak yang Berhadapan Dengan Hukun Dalam Sistem Peradilan Pidana Anak. Jurnal Pembaharuan Hukum, 4(1), 58. doi: 10.26532/jph.v4i1.1644, h. 58.

${ }^{7}$ Sukardi, S. (2016). Eksistensi Konsep Restorative Justice Dalam Sistem Hukum Pidana di Indonesia. Legal Pluralism: Journal of Law Science, 6(1).h. 28.

${ }^{8}$ Tridiatno, Y. A. (2015). Keadilan Restoratif. Yogyakarta: Cahaya Atma Pustaka. h.27. 
peraturan hukum. Semangat yang dibangun dalam keadilan restoratif adalah mencari solusi, memperbaiki, perdamaian, dan membangun kembali hubungan. ${ }^{9}$

Pada sisi lain Rena Yulia mengemukakan bahwa putusan hakim (sebagai jawaban penyelesaian konflik) yang memuat keadilan restoratif diharapkan dapat memberikankeadilan yang membahagiakan bagi para pihakyang berkonflik, yakni pelaku, korban, dan masyarakat. ${ }^{10}$ Hasil kajian Sidik Sunaryo dan Shinta Ayu Purnamawati terkait paradigma putusan hakim yang baik dan benar dalam kasus korupsi menunjukkan putusan hakim yang benar adalah yang memenuhi rasa keadilan masyarakat, sedangkan putusan yang baik adalah yang memenuhi kebenaran rasio. ${ }^{11} \mathrm{Hal}$ ini tentu dapat menjadi acuan, namun penelitian ini husus mengkaji terkait paradigma putusan hakim perspektif restorative justice.

Restorative justice sebagai paradigma dalam pemidanaan diharapkan dapat menjadi alternatif penanganan tindak pidana atau kejahatan yang mengutamakan pemulihan keseimbangan hubungan antara pelaku dan korban. ${ }^{2}$ Sangat diperlukan langkah yang progresif dan responsif untuk merubah paradigma positivimeke arahparadigma keadilan restoratif, sehingga dapat mewujudkan keadilan bagi semua pihak dalam sebuah putusan hakim. Peran seorang hakim dalam hal ini tentu sangatlah penting dalam menciptakan putusan hakim yang memuat keadilan restoratif.Untuk itu diperlukan sebuah konstruksi atau model putusan hakim yang berparadigma keadilan restoratif sebagai gambaran dan pedoman kedepannya.

Tujuan umum dalam penulisan ini untuk menemukan paradigma keadilan restoratifdalam putusan hakim, khususnya menemukan paradigma keadilan restoratif hakim dalam memutus perkara pidana dan konstruksi putusan hakim yang berparadigma Keadilan Restoratif (Restorative Justice). Putusan pengadilan yang memuat paradigma keadilan restoratif menjadi hal yang tepat dan cocok untuk diterapkan di Indonesia, sehingga dapat menjadi sarana pemenuhan keadilan bagi semua pihak. Penelitian ini dapat menjadi sebuah arahan bagi hakim dalam menjatuhkan putusannya sehingga memuat nilai kebaruan kedepannya khususnya perubahan paradigma bagi hakim dalam memutus.Penelitian ini bermanfaat untuk penegakan hukum, bagi penegak hukum, dan bagi masyarakat. Penelitian ini urgen untuk dilakukan seiring dengan perkembangan hukum yang menuntut keadilan dan pemenuhan keadilan bagi masyarakat.

\section{Metode Penelitian}

9Prayitno, K.P (2012). Restorative Justice untuk Peradilan di Indonesia (Perspektif Yuridis Filosofis dalam Penegakan Hukum In Concreto. Jurnal Dinamika Hukum, 12 (3), 412. doi: 10.20884/1.jdh.2012.12, h. 412.

${ }^{10} Y u l i a$, R. (2012). Penerapan Keadilan Restoratif Dalam Putusan Hakim: Upaya Penyelesaian Konflik Melalui Sistem Peradilan Pidana. Jurnal Yudisial, 5(2), 226. doi: 10.29123/jy.v5i2.155, h. 226.

11Sunaryo, S., \& Purnamawati, S. A. (2019). Paradigma Hukum Yang Benar dan Hukum yang Baik (Perspektif Desain Putusan Hakim Perkara Korupsi di Indonesia). Hukum Pidana dan Pembangunan Hukum, 1(2). h. 8.

${ }^{12}$ Sosiawan, U. M. (2017). Perspektif Restorative Justice Sebagai Wujud Perlindungan Anak Yang Berhadapan Dengan Hukum (Perspective of Restorative Justice as a Children Protection Against the Law). Jurnal Penelitian Hukum De Jure, 16(4), 426. doi: 10.30641/dejure.2016, h. 426. 
Penelitian ini adalah penelitian dengan jenis penelitian hukum normatif yang mengkaji konsep keadilan restoratif dengan putusan hakim sebagai objek kajian, khususnya dalam paradigma hakim dalam memutus. Dalam membahas permasalahan penelitian ini menggunakan lima jenis pendekatan. Pertama, adalah pendekatan kasus. Penulis akanmengkaji putusan pengadilan yang telah memiliki kekuatan hukum yang akan merujuk pada kasus-kasus yang terkait dengan keadilan restoratif. Kedua, adalah pendekatan perundang-undangan yang mendukung penerapan keadilan restoratif. Ketiga, adalah pendekatan konseptual, seperti konsep keadilan restoratif dan konsep paradigma hakim. Keempat, pendekatan sejarah, khususnya sejarah darikeadilan restoratif.Kelima, pendekatan perbandingan dengan memahami penerapan keadilan restoratif di negara-negara lainnya. Penelitian ini menggunakan bahan hukum primer (Peraturan Perundang-undangan dan Yurisprudensi) dan bahan hukum sekunder (doktrin). Bahan-bahan hukum diidentifikasi, diklasifikasi dan dikumpulkansecara sistematis dengan metode bola salju. Bahan-bahan hukum yang ada selanjutnya akan dianalisis dengan teknik analisis bahan hukum berupa teknik deskriptif, komparatif, evaluatif, interpretasi, tkonstruksi, dan argumentatif.

\section{Hasil Dan Pembahasan}

\subsection{Paradigma Keadilan Restoratif Hakim Dalam Memutus Perkara Pidana}

Paradigma seorang hakim menjadi hal yang penting dalam sebuah putusan hakim, karena paradigma hakim akan menentukan isi putusan yang akan dijatuhkan. Terkait filosofi putusan hakim M. Natzir Asnawi menyatakan bahwa putusan hakim tidak hanya dilihat dari satu dimensi saja. Putusan hakim harus dilihat dan dipahami dari berbagai dimensi yang mengintarinya. Putusan hakim dalam hal ini tidak semata-mata hanya persoalan normatif dan yuridis semata, namun juga tentang ketaatan hukum, efektifitas hukum, nilai-nilai dan kultur di masyarakat, serta paradigma hakim dalam memutus perkara. ${ }^{13}$ Persoalan paradigma menjadi hal yang penting sehingga perlu ditanamkan paradigma yang cocok dimiliki oleh seorang hakim di Indonesia sehingga mampu menghasilkan putusan pengadilan yang ideal.

Paradigma hakim dalam memutus suatu perkara menjadi sangat menentukan dalam menciptakan putusan pengadilan yang ideal. Hakim dalam konteks ini memiliki kebebasan dan independensi sehingga hakim menjadi pihak yang strategis dalam mewujudkan hukum yang progresif dan responsif dalam setiap putusannya.

M. Natsir Asnawi menulis bahwa independensi peradilan menjadi faktor mendasar dan paling utama bagi pengadilan dalam menegakkan kebenaran dan keadilan. Proses mengadili adalah hasil dari olah pikir, rasa, dan cipta, serta nurani sebagai pengendali dan pengontrol yang netral dari berbagai kepentingan dan intimidasi. ${ }^{14} \mathrm{M}$. Natsir Asnawi juga menulis bahwa hakim pada kondisi dan situasi tertentu bahkan dituntut untuk melakukan terobosan hukum untuk keadilan. ${ }^{15}$ Hal inilah yang saat ini dikenal dengan nama hukum progresif sebagai cerminan dari keadilan restoratif yang telah hadir dalam perkembangan hukum pidana di Indonesia.

\footnotetext{
${ }^{13}$ Asnawi, M. N. Op.Cit. h. 129.

${ }^{14} \mathrm{Ibid}$.

${ }^{15}$ Ibid.
} 
Keadilan restoratif telah mewarnai perkembangan hukum di dunia dan menjadi terobosan demi keadilan bagi semua pihak. Idealnya putusan pengadilan harus mencerminkan nilai-nilai keadilan, kepastian hukum, dan kemanfaatan, namun dalam prakteknya sangat sulit untuk memuat atau mengakomodasikan ketiga nilai tersebut dalam sebuah putusan pengadilan. Hal ini dikarenakan hakim seringkalimenghadapi dilema manakala harus memilih antara kepastian hukum dan keadilan yang nyatanya harus dipenuhi secara bersamaan. Ketika kepastian hukum dan keadilan tidak berjalan beriringan akan menimbulkan dilema hakim dalam mewujudkan keadilan. Pilihan ini tentu menjadi subjektif. Fenomena yang terjadi menunjukkan bahwa keadilan seringkali dikorbankan dalam penegakan hukum, karena hakim memutus berdasarkan hukum (memililih kepastian hukum). Keyakinan hakim dalam konteks ini menjadi subyektif, sehingga paradigma seorang hakim sangat menentukan isi dari putusan yang dibuatnya. Secara paradigma keilmuan hakim hendaknya mempertimbangkan dan mewujudkan nilai keadilan, kepastian hukum, dan kemanfaatan dalam mengadili suatu perkara, namun apabila tidak memungkinkan maka sesuai dengan asas prioritas keadilanlah yang harus diutamakan. Bahkan ada aliran yang menyatakan bahwa keadilan adalah tujuan yang utama. Hal ini menunjukkan bahwa keadilan menjadi tujuan hukum yang sangat penting. Proses-proses transformasi dari keinginankeinginan sosial akan keadilanharus diterjemahkan menjadi peraturan-peraturan perundang-undangan baik dalam konteks politik dan sosiologis serta tercermin dalam putusan hakim dipengadilan. ${ }^{16}$

Seiring dalam perkembangannya, banyak teori dan jenis keadilan yang muncul dari filsuf atau ahli hukum. Berbagai teori dan jenis keadilan ini juga secara teoritis menumbuhkan pemahaman, keyakinan, serta arah dalam menentukan keadilan apa yang harus dicapai. Apabila dikaji, keadilan yang dibutuhkan oleh bangsa Indonesia dan penegakan hukum di Indonesia adalah keadilan restoratif. Hakim hendaknya berparadigma keadilan restoratifdalam mengadili dan memutus suatu perkara pidana sehingga dapat memberikan keadilan bagi semua pihak.

Keadilan restoratif telah menjadi konsep pemikiran yang merespon pengembangan sistem peradilan pidana dengan menitikberatkan pada keterlibatan masyarakat dan korban dalam penyelesaian perkara pidana. Penggunaan restorative justice sebagai upaya penyelesaian perkara pidana, sudah diakui secara internasional. Konsep keadilan restoratif (restorative justice) juga telah sesuai dengan hukum yang hidup dalam masyarakat Indonesia atau yang dikenal dengan hukum adat yang ada di berbagai daerah di Indonesia. ${ }^{17}$

Indonesiamulai menerapkan keadilan restoratif pada ranah peradilan anak yang kini dikenal dengan nama diversi. Undang-undang Sistem Peradilan Pidana Anak ini dapat menjadi dasar bahwa keadilan restoratif dapat diterapkan dalam ranah hukum pidana namun masih sebatas penyelesaian tindak pidana anak, sehingga undang-undang ini tidak berlaku bagi orang dewasa.Diversi diatur dalam Undang-Undang RI Nomor 11

\footnotetext{
16Sudiarawan, K. A., Tanaya, P. E., \& Hermanto, B. (2020). Discover the Legal Concept in the Sociological Study. Substantive Justice International Journal of Law, 3(1), 94-108.

${ }^{17}$ Candra, S. (2013). Restorative Justice: Suatu Tinjauan Terhadap Pembaharuan Hukum Pidana di Indonesia. Jurnal Rechts Vinding: Media Pembinaan Hukum Nasional, 2(2),h. 271.
} 
Tahun 2012 Tentang Sistem Peradilan Pidana Anak yang bisa diterapkanpada semua tingkat pemeriksaan (penyidikan, penuntutan, dan persidangan di pengadilan).

Restorative justice tidak hanya dapat berupa penyelesaian di luar pengadilan seperti diversi, mediasi penal, dan lain-lain, namun menurut penulis keadilan restoratif dapat menjadi paradigma penuntun hakim dalam mengadili suatu perkara demi mencapai keadilan bagi semua pihak. Restorative justice dapat menjadi keadilan yang mendasari sebuah pertimbangan hakim dalam memutus sehingga putusan pengadilan mencerminkan keadilan restoratif yang memberikan keadilan bagi semua pihak (korban, pelaku, dan masyrakat).

Menurut penulis, peradilan pidana di Indonesia dalam praktiknya tidak memberikan kedudukan yang kuat bagi seorang korban. Penyelenggaraan peradilan pidana dalam hal ini tidak memberikan cukup ruang bagi korban kejahatan untuk mendapatkan pemulihan atau perbaikan. Fokus utama dalam peradilan pidana faktanya lebih ditujukan untuk mengadili pelaku kejahatan dan menghukum pelaku kejahatan dengan menjatuhkan pidana berdasarkan Pasal $10 \mathrm{KUHP}$, sedangkan korban tidak cukup mendapatkan perhatian. Jaksa akan melaksanakan tugasnya yang akan mewakili korban dalam menuntut pelaku, dan tidak selalu tuntutan jaksa dapat mewakili segala tuntutan korban terutama dalam memenuhi hak-hak korban kejahatan sebagai bentuk upaya pemulihan atau perbaikan. Pada dasarnya pemulihan atau perbaikan inilah yang menjadi kebutuhan utama korban, dan hal ini dapat ditemukan dalam keadilan restoratif.

Memberikan keadilan bagi semua pihak tentu bukanlah hal yang mudah, untuk mencapai keadilan bagi semua pihak ini perlu adanya keterlibatan semua pihak (terutama bagi korban, pelaku, dan masyarakat yang juga terkena dampak kejahatan). Hal inilah yang perlu dipahami hakim dalam memutus dan menjadikannya sebagai dasar pertimbangan dalam memutus. Keadilan restoratif akan memberikan keadilan bagi semua pihak dengan memenuhi hak-hak dan kebutuhan semua pihak. Yoachim Agus Tridiatno menekankan bahwa keadilan restoratif mementingkan pemulihan korban, pelaku kejahatan, dan masyarakat. Fokus keadilan restoratif ada pada pemulihan atau perbaikan seperti keadaan semula sebelum kejahatan terjadi.

Pada dasarnya restorative justice adalah konsep yang sederhana. Dalam konteks ke Indonesiaan, restorative justice berarti penyelesaian secara adil dengan melibatkan pelaku, korban, keluarga dan pihak lain yang terkait dan bersama-sama mencari penyelesaian tindak pidana dan implikasinya yang mengutamakan pemulihan kembali pada keadaan semula. ${ }^{18}$ Restorative justiceakan menjadi konsep yang menjunjung tinggi nilai HAM dan bersifat humanis. ${ }^{19}$

Yoachim Agus Tridiatno mengemukakan 3 (tiga) prinsip dasar dalam keadilan restoratif, yakni: 1) mengutamakan pemulihan atau restorasi bagi semua pihak (korban, pelaku, dan masyarakat). 2)Fokus pada kebutuhan korban, pelaku kejahatan,

${ }^{18}$ Arief, H., \& Ambarsari, N. (2018). Penerapan Prinsip Restorative Justice Dalam Sistem Peradilan Pidana di Indonesia. Al-Adl: Jurnal Hukum, 10(2). doi: 10.31602/al-adl.v10i2.1362, h. 178.

${ }^{19}$ Istiqamah, D. T. (2018). Analisis Nilai Keadilan Restoratif Pada Penerapan Hukum Adat di Indonesia. Veritas et Justitia, 4(1). doi: 10.25123/vej.2914, h. 210. 
dan masyarakat. 3) Memerhatikan kewajiban dan tanggungjawab yang muncul oleh karena kejahatan. ${ }^{20}$ Prinsip-prinsip dasar ini dapat dijadikan pegangan hakim dalam penerapan paradigma keadilan restoratif dalam membuat putusan.

Keadilan restoratif juga perlu dikaji berdasarkan perkembangan tujuan pemidanaan. Seiring dengan perkembangan zaman dan kebutuhan serta tuntutan masyarakat, secara teoritis tujuan pemidanaan juga berkembang tidak lagi bersifat pembalasan atau retributif namun telah berkembang ke arah yang lebih modern yang kini dikenal dengan keadilan restoratif (restorative justice). Hal ini seharusnya diikuti oleh hakim dalam hal menjatuhkan putusan terkait dengan tujuan pemidanaan sebagai dasar pertimbangan memutus. Ali Sodiqin mengemukakan bahwa pendekatan retributive justice yang bersifat pembalasan yang dianut oleh hukum pidana Indonesia perlu direformasi dan digantikan dengan tujuan pemidanaan yang mengarah pada restorative justice. ${ }^{21}$ Tujuan pemidanaan yang bersifat pembalasan/retributif tanpa memperdulikan aspek lain misalnya proses kemanfaatantentu tidak cocok lagi diterapkan saat ini. Bahkan Muladi dan Barda Nawawi Arief menulis bahwa, teori retributive merupakan "a relic of barbarism". 22

Mengacu pada prinsip ultimum remedium, perlu direalisasikan dalam tujuan pemidanaan yang semakin menarik untuk dikaji saat ini yakni restorative (keadilan restoratif/restorative juctice). Restorative juctice menjadi tujuan pemidanaan yang bukan bersifat pembalasan yang dianut dalam tujuan pemidanaanyang sifatnya retributifnamun berorientasi pada "pemulihan/perbaikan". Paradigma tujuan pemidanaan yang masih bersifat pembalasan atau retributif harusnya bergeser pada paradigma keadilan restoratif yang memberi kemanfaatan bagi semua pihak.

Secara subyektif, hakim memiliki paradigma yang berbeda-beda namun untuk mencapai keadilan bagi semua pihak hendaknya hakim menerapkan keadilan restoratif dalam setiap putusannya. Putusan pengadilan harus mengarah pada hukum yang progresif dan responsif dengan mengedepankan nilai keadilan bagi masyarakat. Tidak hanya melihat aspek yuridisnya (asas legalitasnya saja) namun juga mengkajinya secara sosiologis dan filosofis.

M. Syamsudin menyatakan bahwa hermeneutika hukum mempunyai setidak-tidaknya dua makna dalam pembuatan putusan hakim, yaitu sebagai metode interprestasi dan berhubungan dengan teori penemuan hukum. ${ }^{23}$ Putusan yang ideal harus memenuhi landasan yuridis, sosiologis, dan filosofis yang lebih mengutamakan keadilan bagi masyarakat luas.

Pembuatan sebuah putusan pengadilan berdasarkan paradigma yang digunakan oleh hakim juga berkaitan dengan penalaran, yang bisa dikaji berdasarkan aspek ontologi, epistemologi, dan aksiologinya:Pertama, dimensi ontologis (hakikat hukum yang

\footnotetext{
${ }^{20}$ Tridiatno, Y.A. Op.Cit. h. 34.

${ }^{21}$ Sodiqin, A. (2015). Restorative Justice dalam Tindak Pidana Pembunuhan: Perspektif Hukum Pidana Indonesia dan Hukum Pidana Islam. Asy-Syir'ah: Jurnal Ilmu Syari'ah dan Hukum, 49(1), 64. doi: 10.30656/ajudikasi.v2i1.575, h. 64.

${ }^{22}$ Muladi dan Arief, B.N. Op.Cit, h. 150.

23Syamsudin, M. (2012), Konstruksi Baru Budaya Hukum Hakim, Jakarta: Kencana Prenada Media Grup. h. 8.
} 
ditetapkan). Kedua, dimensi epistemologis, yaitu tentang metode atau pendekatan yang digunakan si subyek dalam berhubungan dengan obyek telaahnya.Ketiga, dimensi aksiologis, yakni tujuan yang ingin dicapai oleh hukum apakah keadilan, kemanfaatan, atau kepastian hukum. ${ }^{24} \mathrm{Hal}$ ini sangat penting diketahui oleh seorang hakim yang akan membentuk paradigmanya dalam menjatuhkan sebuah putusan.

Pada dasarnya, pandangan hakim terkait makna hukum akan memengaruhi isi putusan hakim dan pandangan hakim ini akan sangat dipengaruhi oleh paradigma hakim itu sendiri. ${ }^{25}$ Dengan demikian dapat diketahui bahwa, paradigma seorang hakim sangat menentukan di dalam proses pembuatan sebuah putusan. Paradigma yang digunakan hakim juga menentukan atau mencerminkan isi dari sebuah putusan, oleh sebab itu pemahaman prinsip-prinsip, dasar, dan konsep keadilan restoratif perlu dipahami dan diterapkan oleh hakim dalam memutus suatu perkara.

\subsection{Konstruksi Putusan Hakim yang Berparadigma Keadilan Restoratif}

Putusan pengadilan dalam perkara pidana memiliki sistematika baku dalam Kitab Undang-Undang Hukum Pidana (KUHAP), sehingga putusan pengadilan harus disusun berdasarkan KUHAP. Tidak hanya dalamaspek formil, putusan pengadilan juga perlu disusun sedemikian rupa sehingga memudahkan dalam memahami isi putusan. Sistematika putusan memang sangat penting, namun isi putusan pengadilan (substansi) juga sangat penting sebagaimana dikatakan bahwa putusan sebagai mahkota hakim dan menjadi produk pengadilan yang paling menentukan karena menentukan nasib terdakwa dalam hal putusan yang akan dijatuhkan oleh hakim.

Sistematika putusan pengadilan telah diatur dalam beberapa pasal dalam KUHAP yaitu diatur dalam Pasal 197 ayat (1) KUHAP dan Pasal 199 KUHAP. Sebagaimana yang telah diuraikan dalam 3.1, secara substansi putusan pengadilan idealnya memuat nilai-nilai keadilan restoratif. Hakim dalam memutus suatu perkara pidana dengan paradigma keadilan restoratif akan mempertimbangkan keadilan bagi semua pihak (korban, pelaku kejahatan, dan masyarakat). Hakim melalui paradigma keadilan restoratif tidak memutus berdasarkan tujuan pemidanaan yang retributif/pembalasan namun dengan pertimbangan tujuan untuk pemulihan atau perbaikan para pihak. Hakim dalam penyusunan putusan pengadilan hendaknya berpegangan pada konsep, prinsip, dan dasar-dasar dari keadilan restoratif yang mengutamakan pemulihan atau perbaikan para pihak, pemenuhan kebutuhan para pihak serta mengutamakan kemanfaatan. Putusan pengadilan hendaknya dapat memberikan keadilan, kemanfaatan, dan kepastian hukum, serta memuat landasan filosofis, yuridis, dan sosiologis sehingga sistematik dan komprehensif. Inilah yang menjadi dasar memutus yang berparadigma keadilan restoratif atau dengan kata lain sebagai kontruksi/model acuan hakim untuk membuat suatu putusan yang berparadigma keadilan restoratif.

Sejalan dengan paradigma keadilan restoratif putusan yang dihasilkan akan selaras dengan hukum yang progresif dan responsif. Putusan pengadilan yang berdasarkan paradigma keadilan restoratif juga akan bersifat humanis dan mencerminkan keadilan

${ }^{24} \mathrm{Ibid}$.

25Ibid. h. 206. 
bagi semua pihak. Putusan pengadilan yang berparadigma keadilan restoratif akan meminimalkan ketidakpuasan terhadap putusan, meminimalkan rasa menang-kalah sebagaimana dirasakan dalam penyelesaian melalui peradilan konvensional karena keadilan restoratif memberikan ruang untuk memperoleh win-win solution, dan menghindari adanya permusuhan atau balas dendam yang kerap ditimbulkan dari hasil putusan pengadilan.

Apabila dikaji dalam berbagai putusan hakim dapat diketahui bahwa masih ada putusan yang belum mencerminkan keadilan restoratif, namun apabila ditelusuri dapat ditemukan beberapa yurisprudensi yang mencerminkan hakim yang berparadigma keadilan restoratif dalam memutus suatu kasus pidana. Dalam konteks ini, hakim mempertimbangkan keadilan restoratif sebagai dasar pertimbangan dalam menjatuhkan hukuman. Melalui keadilan restoratif, dalam situasi dan kondisi tertentu hukuman dapat diperingan dan bahkan dapat membebaskan terdakwa.

Putusan pengadilan yang memuat paradigma keadilan restoratif dapat dilihat dalam beberapa yurisprudensi/putusan pengadilan dibawah ini:

1) Putusan Pengadilan Negeri Jakarta Utara Nomor: 46/Pid/UT/781/WAN tanggal 17 Juni 1978 tentang kasus Ny. Elda yang melepaskan tertuduh dari segala tuntutan hukum karena adanya perdamaian.

2) Putusan Mahkamah Agung RI Nomor 1644K/Pid/1988 tanggal 15 Mei 1991 tentang eksistensi peradilan adat yang meniadakan tuntutan pidana.

3) Putusan Mahkamah Agung Nomor 984K/Pid/1996 tanggal 30 Januari 1996 tentang kasus yang telah dijatuhi sanksi adat maka tuntutan jaksa tidak dapat diterima.

4) Putusan Mahkamah Agung Nomor: 107/PK/Pid/2006 tanggal 21 November 2007 tentang perdamaian yang meringankan hukuman.

Contoh putusan-putusan hakim ini dapat menjadi pedoman bagi hakim ketika akan memutus suatu kasus sehingga akan mencerimkan keadilan restoratif.

\section{Kesimpulan}

Paradigma hakim yang memandang tujuan pemidanaan sebagai bentuk pembalasan atau retributif tidak cocok lagi diterapkan. Secara teoritis tujuan pemidanaan telah berkembang ke arah yang lebih modern yang kini dikenal dengan keadilan restoratif (restorative justice) yang mengutamakan "pemulihan/perbaikan". Paradigma keadilan restoratif akan berupaya memberikan keadilan, kepastian hukum, dan kemanfaatan serta mewujudkan hukum yang progresif dan responsif, sehingga tepat digunakan sebagai paradigma hakim dalam memutus suatu perkara.Dalam suatu perkara pidana dengan paradigma keadilan restoratif, hakimtidak hanya memutus berdasarkan undang-undang semata,akantetapi juga mempertimbangkan keadilan bagi semua pihak (korban, pelaku kejahatan, dan masyarakat). Selain itu, hakim juga tidak memutus berdasarkan tujuan pemidanaan yang retributif/pembalasan namun berpegangan pada nilai-nilai, konsep, prinsip, serta dasar-dasar dari keadilan restoratif yang mengutamakan pemulihan atau perbaikan para pihak, pemenuhan kebutuhan para pihak serta mengupayakan kemanfaatan. Putusan pengadilan hendaknya memberikan keadilan, kemanfaatan, dan kepastian hukum, serta memuat landasan filosofis, yuridis, dan sosiologis sehingga sistematik dan komprehensif. 


\section{Daftar Pustaka / Daftar Referensi}

\section{$\underline{\text { Buku }}$}

Asnawi, M. N. (2014). Hermeneutika Putusan Hakim. Yogyakarta: UII Press.

Tridiatno, Y.A. (2015). Keadilan Restoratif. Yogyakarta: Cahaya Atma Pustaka.

Syamsudin, M. (2012), Konstruksi Baru Budaya Hukum Hakim. Jakarta: Kencana Prenada Media Grup.

\section{Jurnal}

Arief, H., \& Ambarsari, N. (2018). Penerapan Prinsip Restorative Justice Dalam Sistem Peradilan Pidana di Indonesia. Al-Adl: Jurnal Hukum, 10(2). doi: 10.31602/aladl.v10i2.1362.

Candra, S. (2013). Restorative Justice: Suatu Tinjauan Terhadap Pembaharuan Hukum Pidana di Indonesia. Jurnal Rechts Vinding: Media Pembinaan Hukum Nasional, 2(2).

Haryadi, L., \& Suteki, S. (2017). Implementasi Nilai Keadilan Sosial Oleh Hakim Dalam Perkara Lanjar Sriyanto dari Perspektif Pancasila dan Kode Etik Profesi Hakim. Law Reform, 13(2), 165. doi: 10.14710/lr.v13i2.16153.

Istiqamah, D. T. (2018). Analisis Nilai Keadilan Restoratif Pada Penerapan Hukum Adat di Indonesia. Veritas et Justitia, 4(1). doi: 10.25123/vej.2914.

Laksana, A. W. (2017). Keadilan Restoratif Dalam Penyelesaian Perkara Anak yang Berhadapan Dengan Hukun Dalam Sistem Peradilan Pidana Anak. Jurnal Pembaharuan Hukum, 4(1), 58. doi: 10.26532/jph.v4i1.1644.

Nurhafifah, N., \& Rahmiati, R. (2015). Pertimbangan Hakim dalam Penjatuhan Pidana Terkait Hal yang Memberatkan dan Meringankan Putusan. Kanun Jurnal Ilmu Hukum, 17(2).

Prayitno, K.P. (2012). Restorative Justice untuk Peradilan di Indonesia (Perspektif Yuridis Filosofis dalam Penegakan Hukum In Concreto. Jurnal Dinamika Hukum, 12 (3), 412. doi: 10.20884/1.jdh.2012.12.

Septianita, H. (2018). Keadilan Restoratif Dalam Putusan Pidana Anak. Jurnal Yudisial, 11(2), 205. doi: 10.29123/jy.v11i2.290.

Sodiqin, A. (2015). Restorative Justice dalam Tindak Pidana Pembunuhan: Perspektif Hukum Pidana Indonesia dan Hukum Pidana Islam. Asy-Syir'ah: Jurnal Ilmu Syari'ah dan Hukum, 49(1), 64. doi: 10.30656/ajudikasi.v2i1.575.

Sosiawan, U. M. (2017). Perspektif Restorative Justice Sebagai Wujud Perlindungan Anak Yang Berhadapan Dengan Hukum (Perspective of Restorative Justice as a Children Protection Against the Law). Jurnal Penelitian Hukum De Jure, 16(4), 426. doi: 10.30641/dejure.2016. 
Sukardi, S. (2016). Eksistensi Konsep Restorative Justice Dalam Sistem Hukum Pidana di Indonesia. Legal Pluralism: Journal of Law Science, 6(1).

Sudiarawan, K. A., Tanaya, P. E., \& Hermanto, B. (2020). Discover the Legal Concept in the Sociological Study. Substantive Justice International Journal of Law, 3(1), 94-108.

Sunaryo, S., \& Purnamawati, S. A. (2019). Paradigma Hukum Yang Benar dan Hukum yang Baik (Perspektif Desain Putusan Hakim Perkara Korupsi di Indonesia). Hukum Pidana dan Pembangunan Hukum, 1(2).

Syamsudin, M. (2012), Konstruksi Baru Budaya Hukum Hakim, Jakarta: Kencana Prenada Media Grup.

Yulia, R. (2012). Penerapan Keadilan Restoratif Dalam Putusan Hakim: Upaya Penyelesaian Konflik Melalui Sistem Peradilan Pidana. Jurnal Yudisial, 5(2), 226. doi: $\underline{10.29123 / \text { jy.v5i2.155. }}$.

\section{Internet/World Wide Web:}

Komisi Yudisial Republik Indonesia. KY Tekankan Hakim Harus Berintegritas dan Adil. Retrieved fromhttps://wwww.komisiyudisial.go.id/frontend/news_detail/1084/kytekankan-hakim-harus-berintegritas-dan-adil,diakses 2 Juni 2020.

\section{Peraturan Perundang-Undangan}

Kitab Undang-Undang Hukum Pidana (KUHP).

Undang-Undang Republik Indonesia Nomor 8 Tahun 1981 Tentang Hukum Acara Pidana (Lembaran Negara Republik Indonesia Tahun 1982 Nomor 76; Tambahan Lembaran Negara Republik Indonesia Nomor 3209).

Undang-Undang Republik Indonesia Nomor 11 tahun 2012 tentang Sistem Peradilan Anak (Lembaran Negara Republik Indonesia Tahun 2012 Nomor 153; Tambahan Lembaran Negara Republik Indonesia Nomor 5332).

\section{Putusan Pengadilan}

Putusan Pengadilan Negeri Jakarta Utara Nomor: 46/Pid/UT/781/ WAN tanggal 17 Juni 1978, dengan hakim ketua sidang: Bismar Siregar.

Putusan Mahkamah Agung RI Nomor: 107/PK/Pid/2006 tanggal 21 November 2007 dengan hakim ketua sidang: H. Parman Soeparman. 